\title{
Changes in pulsatile LH secretion after ovariectomy in Ile-de-France ewes in two seasons
}

\author{
G. W. Montgomery*, G. B. Martin† and J. Pelletier \\ INRA, Station de Physiologie de la Reproduction, 37380 Monnaie, France
}

\begin{abstract}
Summary. Two experiments were conducted in Ile-de-France ewes to study changes in pulsatile LH secretion in ewes ovariectomized during anoestrus or during the midluteal phase of the oestrous cycle. In Exp. 1, blood samples were taken every $20 \mathrm{~min}$ for $12 \mathrm{~h}$ the day before ovariectomy (Day 0 ). After ovariectomy, samples were taken every $10 \mathrm{~min}$ for $6 \mathrm{~h}$ (10 ewes per group), on Days 1, 3, 7 and 15. In Exp. 2 samples were taken every $10 \mathrm{~min}$ for $6 \mathrm{~h}$ ( 10 ewes per group) on Days $7,15,30,60,90,120,150$ and 180 after ovariectomy. Further samples were taken ( 5 ewes per group) at 9 and 12 months after ovariectomy.

There were significant interactions between season and day of sampling for the interval between LH pulses in both experiments. LH pulse frequency increased within 1 day of ovariectomy and the increase was more rapid during the breeding season. There were clear seasonal differences in pulse frequency in Exp. 2. Compared with ewes ovariectomized in anoestrus, pulse frequency was significantly higher for ewes ovariectomized in the breeding season, from Day 7 until Day 120. Once pulse frequency had increased in ewes about the time of the normal breeding season, pulse frequency remained high and subsequent seasonal changes were greatly reduced.

Pulse amplitude increased immediately after ovariectomy to reach a maximum on Day 7 and there were no differences between season of ovariectomy in the initial changes in amplitude. In Exp. 2, changes in amplitude followed changes in pulse interval and there was a significant interaction between season and day of sampling. There were no significant effects of season on nadir LH concentrations which increased throughout the duration of the experiments.

These results show that, in ovariectomized ewes, $\mathrm{LH}$ pulse frequency observed on a given day depends on time after ovariectomy, season at the time of sampling and on previous exposure of ewes to stimulatory effects of season. The direct effects of season on LH pulse frequency and seasonal changes in sensitivity to steroid feedback may contribute to control of the breeding season and their relative contributions to the beginning and end of the breeding season may differ.
\end{abstract}

\section{Introduction}

Seasonal breeding is a common feature of many sheep breeds at temperate zone latitudes and it has been shown that photoperiod is the principal environmental factor determining the timing of the breeding season (Yeates, 1949; Hafez, 1952). In rams, photoperiod exerts direct effects on LH release in the absence of the gonads and indirect effects through a change in the sensitivity to the

\footnotetext{
* Present address: Invermay Agricultural Research Centre, Private Bag, Mosgiel, New Zealand.

† Present address: M.R.C. Reproductive Biology Unit, Centre for Reproductive Biology, Edinburgh EH3 9EW, U.K.
} 
negative feedback action of gonadal steroids (Pelletier \& Ortavant, 1975a, b). Seasonal changes in the sensitivity to negative feedback by oestrogen in ewes have been demonstrated (Legan, Karsch \& Foster, 1977) and extensively investigated (see Karsch, 1980), leading to the hypothesis that a seasonal change in negative feedback by oestradiol is the major factor controlling seasonal breeding in the ewe.

It has been proposed that there are also direct effects of photoperiod (not mediated by gonadal steroids) on LH pulses in ewes (Goodman \& Karsch, 1980; Karsch, 1980). Oestradiol inhibits the secretion of LH during the anoestrous season primarly by reducing the frequency of pulses (Martin \& Scaramuzzi, 1980; Karsch, 1980; Goodman \& Karsch, 1981b; Wright, Geytenbeek, Clarke \& Findlay, 1981; Goodman, Bittman, Foster \& Karsch, 1982; Martin, Scaramuzzi \& Henstridge, 1983). In the absence of the ovaries, LH pulse frequency is lower during anoestrus than during the breeding season in Suffolk ewes (Karsch, 1980; Goodman \& Karsch, 1981 b; Robinson, Radford \& Karsch, 1982; Goodman et al., 1982), although not in Merino ewes (Martin et al., 1983).

Many of the current hypotheses for control of seasonal breeding and the oestrous cycle have resulted from studies on ovariectomized ewes. It has long been known that $\mathrm{LH}$ concentrations increase after ovariectomy in the ewe (Arendarcik \& Maracek, 1968; Roche, Foster, Karsch \& Dziuk, 1970; Reeves, O'Donnell \& Denorscia, 1972). However, data on the changes in pulsatile release of LH after ovariectomy are limited (Butler, Malvern, Willett \& Bolt, 1972; Reeves et al., 1972; Diekman \& Malvern, 1973; Wright, Stelmasiak \& Anderson, 1983). The effects of season and time after ovariectomy require further investigation to assess the effects of steroid-dependent and -independent effects on changes in gonadotrophin secretion with season.

In any long-term study of the effects of season on $\mathrm{LH}$ release in a single group of ewes, effects of season and time after ovariectomy would be confounded. The aims of the present experiment were to study short-term and long-term changes in pulsatile LH release in ewes ovariectomized during anoestrus or during the breeding season.

\section{Materials and Methods}

Animals and management. Two experiments were conducted with Ile-de-France ewes 2-6 years of age. Ewes were housed in groups of 20 in a light-proof building, isolated from rams, and subjected to normal seasonal changes in daylength $\left(8 \mathrm{~h}\right.$ in December to $16 \mathrm{~h}$ in June at the latitude of $47^{\circ} \mathrm{N}$ at Nouzilly) regulated by electrical clocks adjusted every 2-4 days. In each room, 8 40-W white fluorescent tubes provided a maximum of 300 lux at the level of the ewes' eyes when the animals looked directly at the lights.

The ewes were allowed at least 1 month to adjust to the new environment before the experiments began. Each morning the ewes were fed a diet of $300 \mathrm{~g}$ lucerne pellets, $400 \mathrm{~g}$ wheat and $30 \mathrm{~g}$ mineral supplement, with wheat straw and water ad libitum.

Short-term study. Short-term changes in LH secretion were studied in groups of 10 ewes ovariectomized early in the breeding season, 22 October 1982, or in anoestrus, 23 March 1983. Indwelling catheters were placed in the jugular veins at least 1 day before sampling. Blood samples $(3 \mathrm{ml})$ were collected every $20 \mathrm{~min}$ for $12 \mathrm{~h}$ on the day before ovariectomy. Further samples were collected every $10 \mathrm{~min}$ for $6 \mathrm{~h}$ beginning about $09: 00 \mathrm{~h}$ on Days 1, 3, 7 and 15 after ovariectomy (day of ovariectomy $=$ Day 0 ). Samples were centrifuged and the plasma stored at $-14^{\circ} \mathrm{C}$ until assay.

Long-term study. Long-term changes in LH secretion were studied in groups of 10 ewes ovariectomized during anoestrus, 17 March 1982, or early in the breeding season, 29 September 1982. A series of blood samples were collected from ewes the day before ovariectomy (day of ovariectomy $=$ Day 0 ). Further samples were collected on Days 7, 15, 30 and then at about 30-day intervals until Day 180 (6 months) after ovariectomy. After Day 180, 5 ewes from each group were removed and further samples collected from the remaining 5 ewes at Day 270 ( 9 months) and Day 
365 (12 months) after ovariectomy. In addition, samples were collected on Days 211 and 236 for ewes ovariectomized in March. Blood samples $(5 \mathrm{ml}$ ) were collected by jugular venepuncture every $10 \mathrm{~min}$ for $6 \mathrm{~h}$, beginning at approximately $09: 00 \mathrm{~h}$ on each sampling day, centrifuged and plasma stored at $-14^{\circ} \mathrm{C}$ until assay.

Ewes from both experiments, present before ovariectomy, were studied to determine cyclic ovarian activity. Complete records were available for 8 ewes from March 1982 until September 1982 and for 19 ewes from January 1983 until March 1983. Jugular blood samples were collected twice each week and progesterone concentrations compared by direct semi-quantitative radioimmunoassay with a reference plasma of $1 \mathrm{ng} / \mathrm{ml}$ (Terqui \& Thimonier, 1974). Ewes were considered to have active corpora lutea when the progesterone concentration was greater than that of the reference plasma. The mean onset of the breeding season and the mean onset of anoestrus were defined as the sampling date on which $50 \%$ of ewes had begun or ceased ovarian cycles.

Ovariectomy. Ewes were ovariectomized at mid-ventral laparotomy under anaesthesia, induced by intravenous injection of thiopentone sodium $(10 \mathrm{mg} / \mathrm{kg}$ : Abbott Laboratories, 28380 SaintRemy-sur-Avre, France) and maintained with halothane in air (3-4\%: Fluothane, ICI Ltd, England). The induction injection also contained atropine sulphate $(1 \mu \mathrm{g} / \mathrm{kg}$ : Merum Laboratories, 77001 Melum, France). The ovaries of all ewes were examined at the time of ovariectomy for the presence of corpora lutea. After ovariectomy ewes were given 3 daily injections of antibiotic (150000 i.u. procaine penicillin, $5 \mathrm{~g}$ dihydrostreptomycin: Gist-Brocades, Netherlands). During the breeding season, the ovaries were removed from the ewes on Day 9 of oestrous cycles that had been synchronized with two injections $(125 \mu \mathrm{g}$ each) of a prostaglandin F-2 $\alpha$ analogue (Estrumate: ICI Ltd), 9 days apart.

LH assay. LH was measured in duplicate in a double-antibody radioimmunoassay (Pelletier, Kann, Dolais \& Rosselin, 1968), with the modifications recently described (Pelletier, Garnier, de Reviers, Terqui \& Ortavant, 1982). Results are expressed as ng CNRS-LH-M3. The sensitivity of assays used to measure plasma $\mathrm{LH}$ concentrations in ovariectomized ewes was $0.5 \mathrm{ng} / \mathrm{ml}$. The intraassay coefficient of variation was $<10 \%$ for values of $B / B_{0}$ from 15 to $70 \%$ (30 to $3 \mathrm{ng} / \mathrm{ml}$ respectively). All samples from the same ewe were assayed in the same assay and ewes from the different seasons were equally distributed in assays to prevent confounding between seasons and assays. The inter-assay coefficient of variation was $12 \%$ at $10 \mathrm{ng} / \mathrm{ml}\left(\mathrm{B} / \mathrm{B}_{0}=41 \%\right)$.

To increase the sensitivity of the assay for plasma from entire ewes, the assay was conducted by displacement rather than in competition. Instead of mixing all reagents together on the first day of the assay, iodinated $\mathrm{LH}$ was added 3 days after the start of incubation between plasma and LH antiserum. The sensitivity under these conditions was $0.03 \mathrm{ng} / \mathrm{ml}$. All samples were measured in the same assay and the intra-assay coefficient of variation was $<12 \%$ for values of $B / B_{0}$ from 10 to $55 \%$ ( 1.5 to $0.3 \mathrm{ng} / \mathrm{ml}$ respectively).

Data analysis. Pulses of $\mathrm{LH}$ in individual profiles were defined as described by Goodman \& Karsch (1980). The nadir before pulses was defined as the sample immediately preceding a significant increase in $\mathrm{LH}$ concentration, considered as a pulse within the definition. The nadir after a pulse was defined as the sample with minimum LH concentration following the decrease after the pulse. Amplitude was defined as the change in concentration from the preceding nadir to the maximum concentration for that pulse. Estimations of $95 \%$ confidence limits of nadir samples were calculated using the NIH Radioimmunoassay computer program (number MED 39), one of the BCTIC computer code collection contributed by D. Rodbard, J. Huston, Jr \& P. J. Munsen of the NICHHD, NIH, Bethesda, Maryland, U.S.A. The number of LH pulses, nadirs preceding each pulse, amplitude, and interval since the preceding pulses were calculated for complete pulses in the profile. Incomplete pulses at the beginning of the profile were included in the analyses if the preceding rise in LH concentration was significant, but data for the nadir and amplitude for that pulse were omitted. Incomplete pulses at the end of profiles were included if a significant decline 
occurred before the end of the profile. Pulse frequencies in entire ewes were analysed by the MannWhitney test (Snedecor \& Cochran, 1967). For ovariectomized ewes, mean values for each sampling day were calculated for all variables and data for each experiment analysed by split-plot analyses of variance. Significant differences refer to values of $P<0.05$ unless otherwise stated. Results are given with standard errors of differences (s.e.d.) or standard errors of means (s.e.m.).

\section{Results}

\section{Entire ewes}

From observations of ewes before ovariectomy, the mean onset of the breeding season in 1982 was 25 August and the first ewe began to cycle on 3 August. Mean onset of anoestrus in 1983 was 6 February and the last ewe ceased to cycle by 15 March.

\section{Ovariectomized ewes}

In 227 profiles, 1789 pulses were identified (range per profile $2-12$ ). Three profiles (1\%) from 2 ewes were very irregular and uncharacteristic of regular pulsatile $\mathrm{LH}$ release observed on preceding and subsequent sampling days in the same ewes. Data from these profiles were excluded and treated as missing values for the analyses. Of the total pulses identified, the increase in LH concentration from nadir to peak occurred across two samples on 471 occasions $(26 \%)$. A further 11 pulses were identified according to the criteria of assay variation, but the increase in $\mathrm{LH}$ concentration occurred over 3 samples. These pulses were included in the analyses since exclusion would have disrupted the regularity of the profiles.

Data on the frequency of LH pulses have been analysed by calculating mean intervals between pulses for each day and each ewe. There was marked variation in mean pulse interval for profiles with the same number of pulses (Table 1), especially when the number of pulses was low. Pulse interval was considered to be a more stable and hence appropriate variate for drawing comparisons rather than the number of pulses identified in the 6-h sampling period.

Table 1. The range observed in mean daily pulse interval (short-term experiment) in profiles with the same number of identified pulses

\begin{tabular}{cccc}
\hline & & \multicolumn{2}{c}{ Mean interval (min) } \\
\cline { 3 - 4 } $\begin{array}{c}\text { No. } \\
\text { of pulses }\end{array}$ & $\begin{array}{c}\text { No. } \\
\text { of profiles }\end{array}$ & $\begin{array}{c}\text { Overall } \\
\text { mean }\end{array}$ & Range \\
\hline 4 & 13 & 83 & $70-97$ \\
5 & 18 & 69 & $57-82$ \\
6 & 26 & 57 & $44-64$ \\
7 & 9 & 52 & $47-57$ \\
8 & 6 & 45 & $40-47$ \\
\hline
\end{tabular}

\section{Short-term study}

Mean ewe liveweight was $64 \cdot 2 \mathrm{~kg}$ and did not differ significantly between ewes ovariectomized during anoestrus or the breeding season (61.0 and 67.4. s.e.d. 3.73). All ewes ovariectomized in March were judged to be in anoestrus from previous patterns of plasma progesterone concentration and the absence of corpora lutea. All ewes ovariectomized in October had mid-cycle corpora lutea and the mean ovulation rate was 1.9 (range 1-3). 
Before ovariectomy, during the mid-luteal phase in the breeding season, the mean number of pulses in a 12-h sampling period was 3.3 (range $1-6, \mathrm{~N}=10$ ). The mean nadir was $0.04 \mathrm{ng} / \mathrm{ml}$ (s.e.m. 0.009 ) and the mean pulse amplitude was $0.55 \mathrm{ng} / \mathrm{ml}$ (s.e.m. 0.074). During anoestrus, before ovariectomy the mean number of peaks was $1.7 / 12 \mathrm{~h}$, the mean nadir was $0.03 \mathrm{ng} / \mathrm{ml}$ (s.e.m. 0.003) and the mean pulse amplitude was $2.04 \mathrm{ng} / \mathrm{ml}$ (s.e.m. 0.376). For ewes in anoestrus, pulse frequency was significantly lower and pulse amplitude significantly higher than for ewes during the mid-luteal phase of the breeding season.

In both seasons, the frequency of LH pulses was much higher on Day 1 than frequencies recorded the day before ovariectomy. During the breeding season frequency increased from one pulse every $218 \mathrm{~min}$ to one pulse every $71 \mathrm{~min}$. During anoestrus the frequency increased from one pulse every $424 \mathrm{~min}$ to one pulse every $93 \mathrm{~min}$. The mean pulse interval on Day 1 was significantly shorter when ewes were ovariectomized in the breeding season compared with ewes in anoestrus (s.e.d. 6.70 min; Text-fig. 1). Pulse profiles from individual ewes representing frequencies observed on Day 1 after ovariectomy during anoestrus or the breeding season are given in Text-fig. 2 .

The pattern of change in pulse interval after ovariectomy differed between seasons and the interaction between season and the day of sampling after ovariectomy was significant (Text-fig. 1). During anoestrus there was a progressive decline in the interval between LH pulses to one pulse every $55.1 \mathrm{~min}$ on Day 15 after ovariectomy. In contrast, during the breeding season there was a biphasic change in pulse interval. The interval between pulses on Day 7 was significantly greater $(P<0.01)$ than the mean interval for Day 3 and Day $15(66.4$ compared with $51 \cdot 7 \mathrm{~min}$, s.e.d. $5 \cdot 11)$, although there was some variability between individual ewes in the timing of changes in pulse interval after ovariectomy. In 3 of 10 ewes, pulse interval was increased on Day 3 rather than Day 7. Differences between seasons in pulse interval were not significant on Days 3, 7 or 15 .

In both seasons, changes in amplitude and nadir were similar and interactions between season and time after ovariectomy were not significant for either variable (Text-fig. 1). Pulse amplitude increased significantly from Day.1 to Day $3(4 \cdot 1$ to $5.9 \mathrm{ng} / \mathrm{ml}$, s.e.d. $1 \cdot 11)$ but differences between Days 3, 7 and 15 were not significant. The nadir increased progressively from $1 \cdot 3 \mathrm{ng} / \mathrm{ml}$ on Day 1 to $4 \cdot 2 \mathrm{ng} / \mathrm{ml}$ on Day 15 (s.e.d. $0 \cdot 419$ ).
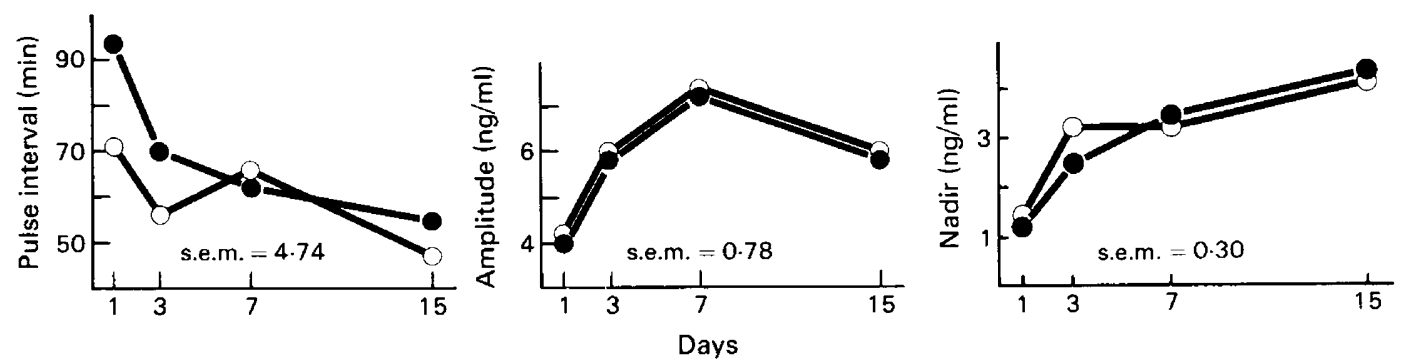

Text-fig. 1. Short-term changes in interval between LH pulses, pulse amplitude and nadir of ewes ovariectomized during anoestrus $(\mathrm{N}=10,0)$ or the mid-luteal phase of the oestrous cycle $(\mathrm{N}=10, \mathrm{O})$.

\section{Long-term study}

Mean ewe liveweight was $61.5 \mathrm{~kg}$ and did not differ significantly between ewes ovariectomized during anoestrus or the breeding season (59.7 and 63.4, s.e.d. 2.54). All ewes ovariectomized in March were judged to be in anoestrus from previous patterns of plasma progesterone concentration and the absence of corpora lutea. All ewes ovariectomized in September had mid-cycle corpora lutea and the mean ovulation rate was $1 \cdot 6$ (range 1-2). 


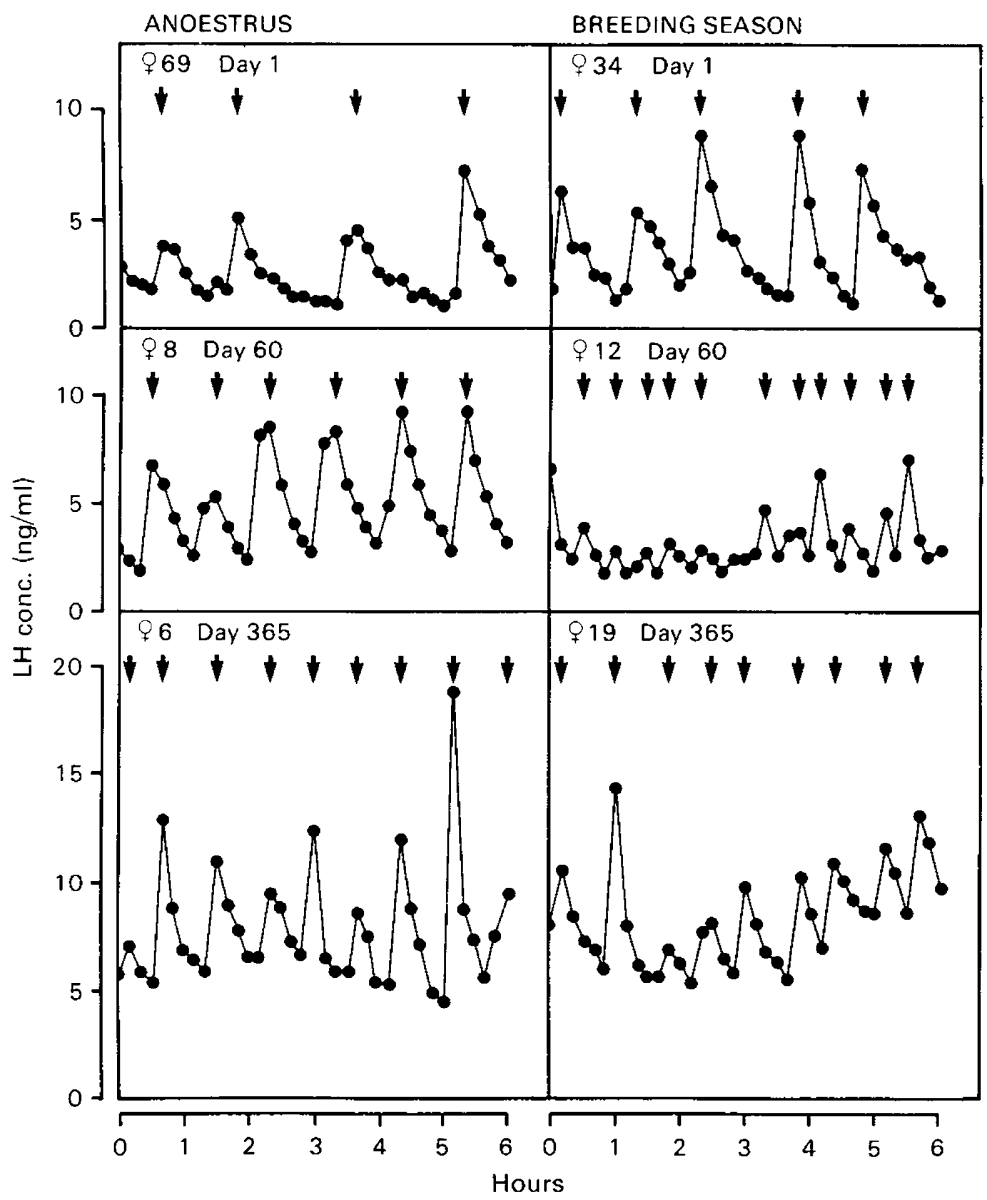

Text-fig. 2. LH profiles in individual ewes representative of pulse frequencies (arrowed) observed at different times after ovariectomy in anoestrus or during a cycle in the breeding season.

During the first 6 months after ovariectomy the pattern of change in pulse interval was different for the two seasons of ovariectomy and the interaction between season and time after ovariectomy was significant $(P<0.01$; Text-fig. 3a, b). For ewes ovariectomized in anoestrus (March), the mean interval between pulses was 58-60 min from Day 15 (March) to Day 120 (July), with the exception of Day 60 (May). At Day 60, mean pulse interval was $50.5 \mathrm{~min}$, significantly lower than Day 30 (60.3 min, April) or Day 90 (59.6 min, June, s.e.d. 2.86). Pulse profiles from individual ewes representing frequencies observed on Day 60 after ovariectomy during anoestrus or the breeding season are given in Text-fig. 2. At Day 150 (August) and Day 180 (September), the interval between pulses decreased, about the time of the onset of the normal breeding season.

In contrast, for ewes ovariectomized during the breeding season, the interval between pulses fell rapidly to reach a minimum of 35.0 min on Day 60 (November; Text-fig. 3a, b). Mean interval gradually rose from Day 60 to Day 180 . Compared with ewes in anoestrus, the interval between pulses was significantly shorter in ewes ovariectomized during the breeding season from Day 7 until Day 120. The mean difference between seasons from Days 30 to 120 was $18 \cdot 1 \mathrm{~min}$ (s.e.m. 1.43). 

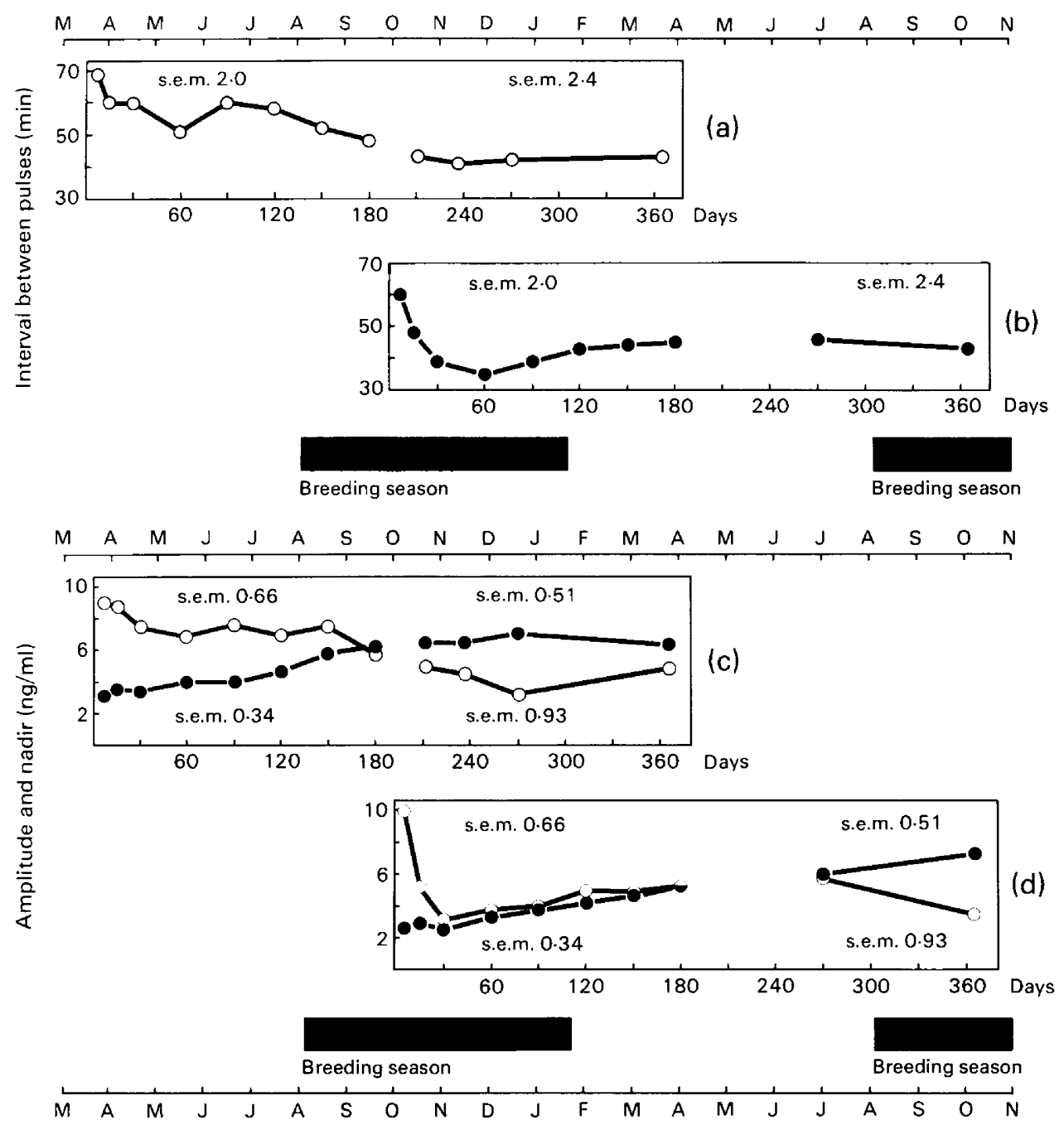

Text-fig. 3. Changes in the mean interval between LH pulses in ewes and in mean amplitude $(O)$ and nadir (O) from LH pulse profiles in ewes ovariectomized in March (a, c) and September (b, d). In each group results to 180 days after ovariectomy are means of 10 ewes and subsequent results are means of 5 ewes. Appropriate standard errors of means (s.e.m.) are indicated on the figure. Data for the breeding season in Ile-de-France ewes are taken from Thimonier \& Mauléon (1969).

Once frequent $\mathrm{LH}$ pulses were established (about the time of the normal breeding season, Textfig. 3), subsequent changes in pulse interval both within and between seasons were small. For ewes ovariectomized during the breeding season differences in pulse interval were not significant between December (Day 90) and March (Day 180). The interval between pulses in these ewes in March was significantly shorter than for ewes ovariectomized in anoestrus and sampled in April (Day 30), June (Day 90), or July (Day 120). Furthermore, the intervals between pulses in the 5 ewes sampled from 6 months to 1 year were not significantly different between sampling times. There were no significant differences between seasons for ewes sampled at Day 270 or Day 365 after ovariectomy. Representative LH profiles for individual ewes on Day 365 are given in Text-fig. 2. 
There was a significant interaction between season and time after ovariectomy for the amplitude of pulses (Text-fig. 3c, d). At Day 7, pulse amplitude was similar for anoestrous and breeding season ewes $(9.0$ and $10 \cdot 0$, s.e.d. 1.22). Thereafter, pulse amplitude was lower for breeding-season ewes except at Day 180. The differences were significant on Days 15, 30 and 90 . In general, the pattern of change in pulse amplitude followed the pattern of change in pulse interval.

There was no significant interaction between season and time after ovariectomy for nadir (Text-fig. 3c, d). The small difference between seasons was not significant. Unlike patterns for pulse interval and amplitude, nadir increased progressively after ovariectomy to reach concentrations of $5-6 \mathrm{ng} / \mathrm{ml}$ by 6 months after ovariectomy. The effect of days after ovariectomy on mean nadir concentrations was highly significant.

\section{Discussion}

Immediately after ovariectomy there were increases in the frequency and amplitude of LH pulses in both seasons. Subsequently, pulse frequency increased further, but this was accompanied by decreases in the amplitude of pulses. The pattern of change in frequency depended on whether ewes were ovariectomized during anoestrus or during the mid-luteal phase of a cycle in the breeding season. However, in the long term, seasonal changes in pulse frequency were greatly reduced.

Seasonal differences in $\mathrm{LH}$ secretion in the absence of the gonads have been observed in rams (Pelletier \& Ortavant, 1975a; Lincoln \& Short, 1980) and ewes (Karsch, 1980; Goodman \& Karsch, 1981a, b; Goodman et al., 1982). Moreover photoperiod influences the pattern of change in gonadotrophin secretion in Soay rams after castration (Lincoln \& Short, 1980). At Days 10-11 after ovariectomy in Suffolk ewes, the frequency of pulses is lower in the anoestrous season compared with the breeding season (Goodman et al., 1982). In the present short-term experiment, differences between seasons were not significant at 7 or 15 days after ovariectomy. Ewes were not sampled on Day 10. Effects of breed, environment, or the timing of ovariectomy during the breeding season may have contributed to the differences in the results.

In the long-term study the pattern of change in LH secretion differed markedly depending on whether ewes were ovariectomized during anoestrus or the mid-luteal phase of the oestrous cycle. Clear differences between groups were evident from Day 7 to Day 120 after ovariectomy with significantly higher pulse frequency (i.e. reduced pulse interval) in ewes ovariectomized during the breeding season. These differences, associated with season of avariectomy, are probably due to the effects of different photoperiod on the ewes during the first 120 days after ovariectomy. From observations on contemporary ewes, the beginning and end of the breeding season for control ewes were similar to times previously reported for Ile-de-France ewes at Nouzilly (Thimonier \& Mauleon, 1969). The pulse frequency of ewes ovariectomized during anoestrus had significantly increased by mid-August before half of the control ewes began to cycle. It further increased during the early breeding season to reach a maximum in November corresponding to the time of maximum pulse frequency observed for ewes ovariectomized during the breeding season.

A notable feature of the present experiment was that, irrespective of the season of ovariectomy, once pulse frequency had increased during the period of a normal breeding season subsequent changes in frequency were greatly reduced. Indeed, pulse frequency in ewes ovariectomized during the early breeding season never slowed to values seen in ewes first ovariectomized during anoestrus. For both seasons of ovariectomy, changes in pulse frequency were not significant from December to April (i.e. from the end of the first breeding season into anoestrus). Furthermore, there was little change in pulse frequency from June to October as ewes ovariectomized during the breeding season entered the period of the normal breeding season for the second time. These data contrast with effects of season observed during the first 6 months after ovariectomy. Based on variation between sampling days within ewes, the minimum change in pulse interval that would have been detected as a significant difference $(P<0.05, n=10)$ was $5.7 \mathrm{~min}$. The marked increase in the nadir $\mathrm{LH}$ 
concentration by 1 year after ovariectomy may have caused some difficulty in detecting lowamplitude LH pulses. However, from consideration of the individual profiles, failure to detect a substantial decrease in pulse frequency as ewes passed from the end of the first breeding season to anoestrus is unlikely to have been caused by problems of pulse detection. Any such decrease in frequency should have been accompanied by an increase in amplitude, reducing problems of pulse detection. The failure of ewes to exhibit marked seasonal changes in LH secretion following effects of a stimulatory season is an important factor in interpreting results from long-term ovariectomized ewes.

During the breeding season, the increase in the frequency of LH pulses immediately after ovariectomy (short-term experiment) was biphasic. There was an initial rapid decrease in the interval between pulses up to 3 days, followed by less frequent pulses at 7 days. During this time, pulse amplitude increased to reach a maximum at 7 days. The initial rapid rise in frequency during the breeding season is at least partly due to removal of corpora lutea at ovariectomy, since LH pulse frequency increases in ewes at luteal regression (Baird \& Scaramuzzi, 1976; Hauger, Karsch \& Foster, 1977; Baird, 1978; Karsch, Foster, Bittman \& Goodman, 1983), but the reason for the biphasic change in pulse frequency is not clear.

In rams, castration results in increases in plasma LH and decreases in the pituitary content of LH (Caraty, 1983). Pituitary content was lowest at Day 15 after castration (first day of measurement) and increased at later observations, suggesting that secretion increases more rapidly than synthesis. It has been shown that oestrogen contributes to the increase in LH pulse frequency during the follicular phase of the oestrous cycle and that the high frequency of pulses during this time may be related to the ability of oestrogen to reduce pulse amplitude (Karsch et al., 1983). In the present experiment, at 3 days after ovariectomy in the breeding season, the frequency was one pulse every $56 \mathrm{~min}$ with a mean amplitude of $6 \mathrm{ng} / \mathrm{ml}$. It appears that such a high rate of release could not be sustained, but whether the decrease in pulse frequency is the result of reduced frequency of GnRH pulses (Caraty, Orgeur \& Thiery, 1982; Clarke \& Cummins, 1982; Levine, Pau, Ramirez \& Jackson, 1982) or pituitary desensitization (Wildt et al., 1981; Karsch et al., 1983) remains to be determined.

In ewes ovariectomized during anoestrus we observed a significant increase in pulse frequency to one pulse every $50 \mathrm{~min}$ in May, but in June pulse frequency was again one pulse every $60 \mathrm{~min}$. A large proportion of Ile-de-France ewes ovulate without showing oestrus in May during midanoestrus, suggesting that the intensity of anoestrus is variable (Thimonier \& Mauleon, 1969). The increase in pulse frequency in May in our ewes corresponds to the period of ovulation in entire ewes and provides evidence that the intensity of effects of season on the hypothalamic-pituitary axis may also vary during anoestrus.

From the present experiment, it is not possible to determine whether seasonal changes in LH pulse frequency were due to feedback effects of extra-ovarian steroids from the adrenal glands or from the food supply. It is unlikely that coumestans, the phyto-oestrogens present in lucerne (Bickoff et al., 1957), were responsible for the seasonal changes observed. The coumestan content of lucerne pellets fed in the present experiment was low and high levels of coumestans have no effect on pulse frequency in ovariectomized anoestrous ewes (G. W. Montgomery, G. B. Martin \& J. Pelletier, unpublished observations).

In conclusion, the pulse frequency observed on a given sampling day in ovariectomized ewes depends on time after ovariectomy, season at the time of sampling and on previous exposure of ewes to stimulatory effects of season. After such stimulation, hypothalamic-pituitary activity continues to produce high-frequency pulses and steroids are required to reduce frequency since oestrogen induces reversible seasonal changes in LH release (Legan et al., 1977; Karsch, Legan, Ryan \& Foster, 1978; Webster \& Haresign, 1983). Therefore, direct effects of season on LH pulse frequency and seasonal changes in sensitivity to steroid feedback may both contribute to the control of seasonal breeding in the ewes and their relative contributions to the beginning and end of the breeding season may differ. 
We thank Alain Locatelli, Marie-Odile Moulin, Didier Chesneau, Benoit Malpaux, and Claude Cornu for technical assistance; and Stuart Crosbie for advice on statistical procedures, G.W.M. was supported by a New Zealand Public Service Study Award and a Bourse de Stage, and G.B.M. by an Overseas Study Award from the Australian Meat Research Council.

\section{References}

Arendarćik, J. \& Maraćek, I. (1968) FSH and LH levels in serum following bilateral ovariectomy in sheep. Endocr. exp. 2, 193-197.

Baird, D.T. (1978) Pulsatile secretion of LH and ovarian estradiol during the follicular phase of the sheep estrous cycle. Biol. Reprod. 18, 359-364.

Baird, D.T. \& Scaramuzzi, R.J. (1976) Changes in the secretion of ovarian steroids and pituitary luteinizing hormone in the peri-ovulatory period in the ewe: the effect of progesterone. J. Endocr. 70, 237-245.

Bickoff, E.M., Booth, A.N., Lyman, R.L., Livingston, A.L., Thompson, C.R. \& DeEds, F. (1957) Coumestrol, a new estrogen isolated from forage crops. Science, N.Y. 126, 969-970.

Butler, W.R., Malvern, P.V., Willett, L.B. \& Bolt, D.J. (1972) Patterns of pituitary release and cranial output of LH and prolactin in ovariectomized ewes. Endocrinology 91, 793-801.

Caraty, A. (1983) Ram hypothalamic-pituitary-gonadal-interactions. Effects of castration and cryptorchidism. Acta endocr., Copenh. 102, 292-298.

Caraty, A., Orgeur, P. \& Thiery, J.C. (1982) Mise en évidence d'une sécrétion pulsatile du LH-RH du sang porte hypophysaire chez la brebis par une technique originale de prelevements multiples. $C$. $r$. hebd. Séanc. Acad. Sci., Paris, Ser. III, 295, 103-106.

Clarke, I.J. \& Cummins, J.T. (1982) The temporal relationship between gonadotropin releasing hormone (GnRH) and luteinizing hormone (LH) secretion in ovariectomized ewes. Endocrinology 111, 1737-1739.

Diekman, M.A. \& Malvern, P.V. (1973) Effect of ovariectomy and estradiol on LH patterns in ewes. $J$. Anim. Sci. 37, 562-567.

Goodman, R.L. \& Karsch, F.J. (1980) Pulsatile secretion of luteinizing hormone: differential suppression by ovarian steroids. Endocrinology 107, 1286-1290.

Goodman, R.L. \& Karsch, F.J. (1981a) A critique of the evidence on the importance of steroid feedback to seasonal changes in gonadotrophin secretion. $J$. Reprod. Fert., Suppl. 30, 1-13.

Goodman, R.L. \& Karsch, F.J. (1981b) The hypothalamic pulse generator; a key determinant of reproductive cycles in sheep. In Biological Clocks in Seasonal Reproductive Cycles, pp. 223-236. Eds B. K. Follett \& D. E. Follett. Wright, Bristol.

Goodman, R.L., Bittman, E.L., Foster, D.L. \& Karsch, F.J. (1982) Alterations in the control of luteinizing hormone pulse frequency underlie the seasonal variation in estradiol negative feedback in the ewe. Biol. Reprod. 27, 580-589.

Hafez, E.S.E. (1952) Studies on the breeding season and of reproduction in the ewe. J. Agric. Sci., Camb. 42, 189-265.

Hauger, R.L., Karsch, F.J. \& Foster, D.L. (1977) A new concept for control of the estrous cycle of the ewe based on the temporal relationships between luteinizing hormone, estradiol and progesterone in peripheral serum, and evidence that progesterone inhibits tonic LH secretion. Endocrinology 101, 807-817.

Karsch, F.J. (1980) Seasonal reproduction: a saga of reversible fertility. Physiologist, Wash. 23, 29-38.

Karsch, F.J., Legan, S.J., Ryan, K.D. \& Foster, D.L. (1978) The feedback effects of ovarian steroids on gonadotrophin secretion. In Control of Ovulation, $\mathrm{pp}$. 29-48. Eds D. B. Crighton, G. R. Foxcroft, N. B. Haynes \& G. E. Lamming. Butterworths, London.

Karsch, F.J., Foster, D.L., Bittman, E.L. \& Goodman, R.L. (1983) A role for estradiol in enhancing luteinizing hormone pulse frequency during the follicular phase of the estrous cycle of sheep. Endocrinology 113, 1333-1339.

Legan, S.J., Karsch, F.J. \& Foster, D.L. (1977) The endocrine control of seasonal reproductive function in the ewe: a marked change in the response to the negative feedback action of estradiol on luteinizing hormone secretion. Endocrinology 101, 818-824.

Levine, J.E., Pau, K-Y.F., Ramirez, V.D. \& Jackson, G.L. (1982) Simultaneous measurement of luteinizing hormone-releasing hormone and luteinizing hormone release in unanesthetized, ovariectomized sheep. Endocrinology 111, 1449-1455.

Lincoln, G.A. \& Short, R.V. (1980) Seasonal breeding; Nature's contraceptive. Recent Prog. Horm. Res. 36, $1-52$.

Martin, G.B. \& Scaramuzzi, R.J. (1980) Effect of androstenedione and oestradiol-17 $\beta$ on the frequency of LH pulses in ovariectomized ewes. Proc. Aust. Soc. Reprod. Biol. 12, 47, Abstr.

Martin, G.B., Scaramuzzi, R.J. \& Henstridge, J.D. (1983) Effects of oestradiol, progesterone and androstenedione on the pulsatile secretion of luteinizing hormone in ovariectomized ewes during spring and autumn. J. Endocr. 96, 181-193.

Pelletier, J. \& Ortavant, R. (1975a) Photoperiodic control of LH release in the ram. I. Influence of increasing and decreasing light photoperiods. Acta endocr., Copenh. 78, 435-441.

Pelletier, J. \& Ortavant, R. (1975b) Photoperiodic control of $\mathrm{LH}$ release in the ram. II. Light-androgens interaction. Acta endocr., Copenh. 78, 442-450.

Pelletier, J., Kann, G., Dolais, J. \& Rosselin, G. (1968) Dosage radio-immunologique de l'hormone lutéinisante plasmatique chez le mouton. Mise au point de la technique de dosage. C. r. hebd. Séanc. Acad. Sci., Paris D 266, 2291-2294.

Pelletier, J., Garnier, D.H., de Reviers, M.M., Terqui, M. \& Ortavant, R. (1982) Seasonal variation in $\mathrm{LH}$ and testosterone release in rams of two breeds. $J$. Reprod. Fert. 64, 341-346. 
Reeves, J.J., O'Donnell, D.A. \& Denorscia, F. (1972) Effect of ovariectomy on serum luteinizing hormone (LH) concentrations in the anestrous ewe. J. Anim. Sci. 35, 73-78.

Robinson, J.E., Radford, H.M. \& Karsch, F.J. (1982) A relationship between frequency of pulsatile $\mathrm{LH}$ secretion and daylength in the ewe. Biol. Reprod. 26, Suppl. 57A, Abstr. 41.

Roche, J.F., Foster, D.L., Karsch, F.J. \& Dziuk, P.J. (1970) Effect of castration and infusion of melatonin on levels of luteinizing hormone in sera and pituitaries of ewes. Endocrinology 87, 1205-1210.

Snedecor, G.W. \& Cochran, W.G. (1967) Statistical Methods, 6th edn. Iowa State University Press, Ames.

Terqui, M. \& Thimonier, J. (1974) Nouvelle méthode radio-immunologique rapide pour l'estimation du niveau de progésterone plasmatique. Application pour le diagnostic précoce de la gestation chez la Brebis et la Chévre. C. r. hebd. Séanc. Acad. Sci., Paris D 279, 1109-1112.

Thimonier, J. \& Mauleon, P. (1969) Variations saisonniéres du comportement d'oestrus et des activités ovarienne et hypophysaire chez les ovins. Annls Biol. anim. Biochim. Biophys. 9, 233-250.

Webster, G.M. \& Haresign, W. (1983) Seasonal changes in $\mathrm{LH}$ and prolactin concentrations in ewes of two breeds. J. Reprod. Fert. 67, 465-471.

Wildt, L., Hausler, A., Marshall, G., Hutchison, J.S., Plant, T.M., Blechetz, P.E. \& Knobil, E. (1981) Frequency and amplitude of gonadotropin-releasing hormone stimulation and gonadotropin secretion in the Rhesus monkey. Endocrinology 109, 376-385.

Wright, P.J., Geytenbeek, P.E., Clarke, I.J. \& Findlay, J.K. (1981) Evidence for a change in oestradiol negative feedback and LH pulse frequency in postpartum ewes. J. Reprod. Fert. 61, 97-102.

Wright, P.J., Stelmasiak, T. \& Anderson, G.A. (1983) Suppressed release of LH in ovariectomized postpartum ewes. J. Reprod. Fert. 67, 197-202.

Yeates, N.T.M. (1949) The breeding season of the sheep with particular reference to its modification by artificial means using light. J. agric. Sci., Camb. 39, $1-43$.

Received 24 April 1984 